\title{
SISTEM PAKAR DIAGNOSA PENYAKIT TANAMAN KELAPA SAWIT BERBASIS ANDROID
}

\author{
Surianti $^{1}$, Nur Ain Banyal ${ }^{2}$ \\ Dosen STMIK Umel Mandiri \\ Jalan Raya Abepura Kotaraja Jayapura-Papua \\ Sur-el : surianti12p@gmail.com ${ }^{1}$, nur.ain.banyal@gmail.com ${ }^{2}$
}

\begin{abstract}
The lack of farmers' knowledge about various palm oil palm plant diseases and how to prevent plant is not attacked by the disease even with the lack of knowledge has led to mistakes in dealing with diseases that attack the oil palm plantations. On the other hand, to meet experts who are experts in the field of agriculture plant oil palm is very difficult, it is necessary for the right technology to solve the problem of oil palm plantations. One way to overcome this problem by building a plant disease expert system palm, to facilitate the farmers know the oil palm plant diseases. There are various methods in an expert system, but here using certainty factor. This study resulted in an expert system that can be used as a means for diagnosing the disease of oil palm trees are diseased, in the application development using Android SDK android studio and used to run android emulator on a computer or pc.
\end{abstract}

Keywords: Android, expert system, Android Studio, SQLite, database, Android SDK, Prototype.

\begin{abstract}
Abstrak: Minimnya pengetahuan petani tentang berbagai penyakit tanaman kelapa sawit dan cara mencegah tanaman tidak terserang penyakit bahkan dengan minimnya pengetahuan telah menyebabkan kesalahan dalam menangani penyakit yang menyerang perkebunan kelapa sawit. Di sisi lain, untuk menemui para ahli yang ahli di bidang pertanian tanaman kelapa sawit sangatlah sulit, maka diperlukan teknologi yang tepat untuk menyelesaikan permasalahan perkebunan kelapa sawit. Salah satu cara untuk mengatasi masalah tersebut dengan membangun sistem pakar penyakit tanaman kelapa sawit, untuk memudahkan para petani mengetahui penyakit tanaman kelapa sawit. Ada berbagai macam metode dalam sistem pakar, namun disini menggunakan faktor kepastian. Penelitian ini menghasilkan suatu sistem pakar yang dapat digunakan sebagai sarana untuk mendiagnosis penyakit pohon kelapa sawit yang terserang penyakit, dalam pengembangan aplikasi menggunakan Android SDK android studio dan digunakan untuk menjalankan emulator android di komputer atau pc.
\end{abstract}

Kata kunci: Kata kunci: Android, sistem pakar, Android Studio, SQLite, database, Android SDK, Prototipe.

\section{PENDAHULUAN}

Perkembangan teknologi dalam bidang pertanian sangat pesat pada beberapa tahun terakhir ini. Beberapa panduan serta cara-cara mengatasi penyakit sudah membanjiri pasaran, termasuk juga tanaman kelapa sawit. Kelapa sawit sering mendapat gangguan hama dan penyakit, serangan hama dan penyakit sangatlah merugikan. Perkembangan pembangunan sistem pakar dalam bidang pertanian diharapkan mampu memperbaiki kualitas pertanian. Memindahkan kepakaran yang dimiliki oleh seorang ahli pertanian ke dalam suatu aplikasi mobile [1]. Pada penelitian ini akan dikembangkan sebuah aplikasi yang dapat digunakan sebagai sarana untuk mengetahui penyakit tanaman kelapa sawit yang bertujuan untuk mempermudah para petani kelapa sawit mengetahui penyakit tanaman kelapa sawit. 
Kelapa sawit (Elaeis guineensis) termasuk tumbuhan pohon, yang tingginya dapat mencapai 24 meter. Kelapa sawit memiliki buah dan bunganya berupa tandan bercabang banyak, buahanya kecil bila masak berwarna merah kehitaman. Daging buah kelapa sawit ini mengandung minyak yang digunakan untuk sebagai bahan minyak goreng, sabun, lilin [2]. Tidak hanya itu, minyak dari kelapa sawit ini juga dimanfaatkan untuk bahan bakar (biodisel). Usaha pertanian kelapa sawit memberikan sumbangan yang sangat besar sebagai sumber devisa dalam menampung pembangunan Nasional yang tinggi. Sebagai komuditas yang mempunyai nilai ekonomis tinggi, selayaknya pengembangan usaha tani kelapa sawit ini mendapatkan perhatian mengingat kontribusinya yang besar dalam perekonomian Nasional. Jadi pertumbuhan dan produktivitas kelapa sawit diharapkan akan meningkat terus-menerus. Salah satu faktor yang dapat mengurangi pertumbuhan dan produktivitas kelapa sawit adalah adanya penyakit tanaman yang bisa di lihat dari gejala-gejala fisik, daun, batang, akar, maupun dari buah sawit yang dihasilkan [3].

Dalam membantu mengenali dan mengendalikan penyakit kelapa sawit ini, maka dibuatlah sebuah sistem pakar untuk mendiagnosis penyakit tanaman kelapa sawit. Dimana sistem pakar ini merupakan sistem komputer yang mampu menirukan penalaran seorang pakar dengan keahlian pada suatu domain atau wilayah pengetahuan tertentu dalam menyelesaikan masalah layaknya seorang pakar. Dengan adanya sistem pakar ini, orang awam juga bisa menyelesaikan masalahnya atau hanya sekedar mencari informasi yang berkualitas yang diperoleh dengan bantuan ahlinya. Sistem pakar ini, diupayakan agar dapat membantu aktifitas para pakar sebagai asisten yang berpengalaman dan mempunyai pengetahuan yang dibutuhkan. Dalam sistem pakar ini mengkombinasikan berbagai macam kaidah-kaidah dan kesimpulan yang di berikan pakar atau ahli dalam bidangnya. Kedua hal tersebut disimpan oleh komputer, yang digunakan dalam pengambilan keputusan permasalahan[4].

\section{METODOLOGI PENELITIAN}

Metode Yang digunakan dalam penelitian ini yaitu forward chaining dengan Langkahlangkah yang ditempuh dalam membantu menyelesaikan penelitian adalah sebagai berikut:

a. Studi Literatur Pada Tahap ini penulis mengumpulkan berbagai macam informasi dan mempelajari materi serta sumbersumber data yang berhubungan dengan sistem pakar. Jenis penyakit tanaman kelapa sawit, gejala-gejala tanaman kelapa sawit beserta pengendaliannya maupun materi lain yang terkait dengan materi penelitian.

b. Analisis Data Pada tahap ini dilakukan pengumpulan fakta-fakta yang mendukung perancangan sistem dengan mengadakan konsultasi kepada seorang pakar atau seorang ahli dalam bidangnya.

c. Implementasi Sistem Pada tahap ini dilakukan sistem yang dirancang di implementasikan ke dalam bentuk coding program

d. Pengujian Pada tahap ini dilakukan pengujian apakah sistem sudah berjalan 
dengan baik dan benar sesuai dengan perancangannya.

e. Penyusunan penelitian pada tahap ini dilakukan penulisan atau dokumentasi hasil analisis dari sistem pakar untuk mendiagnosis penyakit tanaman kelapa sawit.

\subsection{Analisa Masalah}

Penyakit tanaman kelapa sawit merupakan penyakit tanaman yang dapat merugikan para petani kelapa sawit. Penyakit tanaman kelapa sawit ini menyerang tanaman dari mulai pembibitan sampai pada tanaman yang telah berproduksi atau menghasilkan buah [5]. Pada saat ini, macam-macam penyakit dan penanggulangan tanaman kelapa sawit belum banyak diketahui secara luas baik bagi para petani maupun masyarakat luas. Seiring seringnya penyakit kelapa sawit menyerang tanaman kelapa sawit membuat para petani menjadi kewalahan karena keterbatasan pengetahuan dalam mendiagnosis penyakit dan cara penanggulangan penyakit kelapa sawit [6]. Sehingga para petani membutuhkan seorang pakar yang dapat membantu dalam mendiagnosis penyakit kelapa sawit. Dimana seorang pakar kelapa sawit ini tidak disemua Daerah ada seorang pakar sehingga sulit untuk menemui pakar kelapa sawit. Hal ini membuat para petani menjadi kesulitan dalam mendapatkan informasi tentang penyakit kelapa sawit. Pada saat tanaman kelapa sawit terserang penyakit, petani yang kurang pengetahuan tentang penyakit kelapa sawit ini hanya menduga-duga penyakit apa yang menyerang tanaman kelapa sawit tersebut dan melakukan penanggulangan tanpa seorang pakar [7]. Hal ini terkadang membuat tanaman kelapa sawit bukan menjadi sehat tetapi semakin parah. Sehingga dapat mengakibatkan penurunan produksi bahkan sampai membuat tanaman kelapa sawit menjadi mati, karena salah penanggulangan yang disebabkan kuranganya pengetahuan petani dalam penyakit kelapa sawit dan tidak adanya seorang pakar [8].

\subsection{Penyelesaian Masalah}

Berdasarkan permasalahan diatas, perlu adanya aplikasi sistem pakar yang bisa membantu mendiagnosis penyakit tanaman kelapa sawit. Sitem pakar ini, berguna untuk membantu para petani, lembaga penyuluhan dan masyarakat atau orang awam dalam mengatasi penyakit tanaman kelapa sawit dengan cepat dan mudah tanpa harus ke pakar/ahli tanaman kelapa sawit. Sistem pakar ini, memberikan informasi tentang penyakit, gejala, penyebab, beserta pengendalian penyakit tanaman kelapa sawit. Sistem pakar yang dibuat dalam penelitian ini adalah "Sistem Pakar Untuk Mendiagnosis Penyakit Tanaman Kelapa Sawit”.

\subsection{Rancangan Sistem Pakar}

Mesin inferensi berperan sebagai otak dari sistem pakar. Mesin inferensi merupakan komponen yang mengandung mekanisme pola pikir dan merupakan penalaran yang digunakan oleh seorang pakar dalam menyelesaikan masalah. Proses penelusuran yang akan digunakan dalam sistem ini adalah metode forward chaining atau ranut maju [8]. Metode forward chaining ini merupakan metode dimana 
user telah mengetahui gejala-gejala dari penyakit yang terjadi untuk menjawab pertanyaanpertanyaan yang akan diajukan oleh sistem, sehingga dapat ditarik kesimpulan diagnosis penyakit yang dialami oleh tanaman kelapa sawit [10].

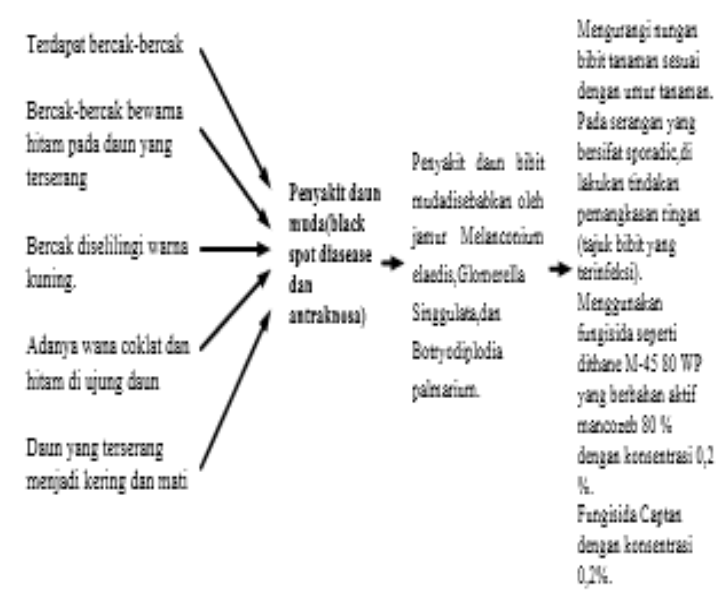

\section{Gambar 1. Diagram proses forward chaining Pada penyakit daun muda}

\subsection{Pohon Keputusan}

Berikut ini pohon keputusan dari sistem pakar untuk mendiagnosis penyakit tanaman kelapa sawit.

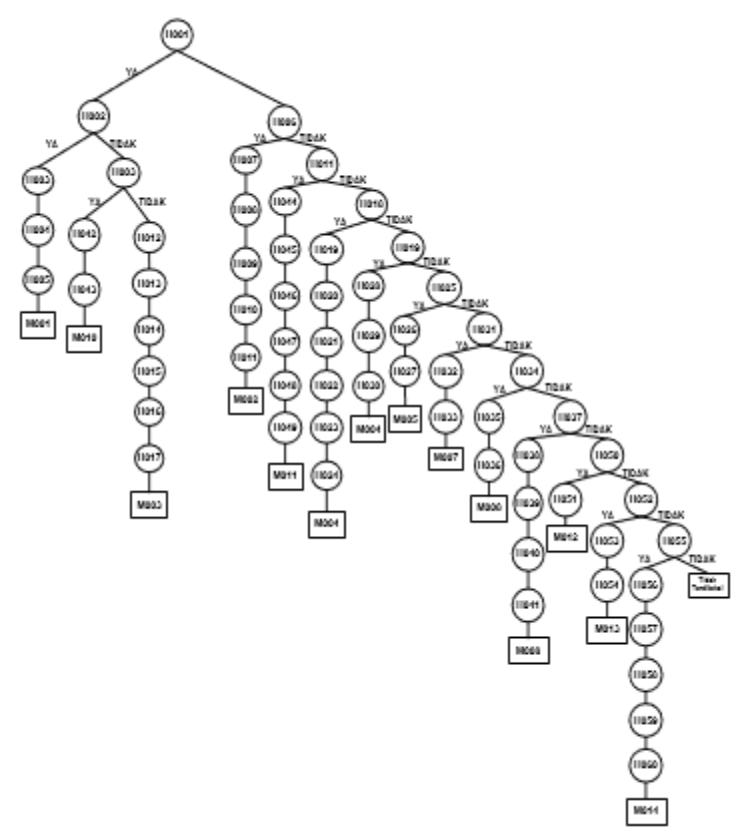

Gambar 2. Pohon Keputusan

\subsection{Alur Flowchart}

Berikut ini alur dari flowchat konsultasi seperti tampak pada gambar 2.

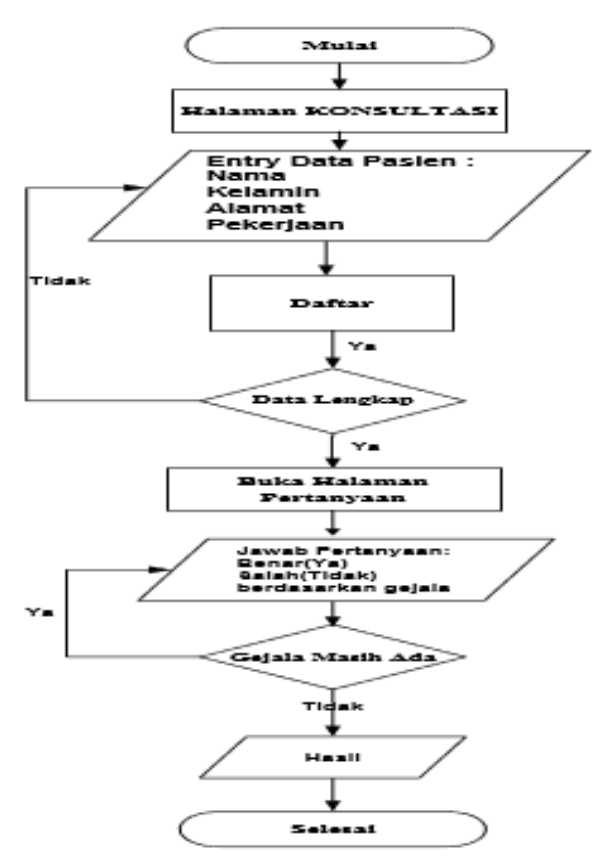

Gambar 3. Alur Flowchart konsultasi

\section{HASIL DAN PEMBAHASAN}

Implementasi sistem ini merupakan tahap terakhir dari proses pengembangan sistem. Setelah sistem dianalisis dan di desain secara rinci dan teknologi telah dipilih dan diseleksi melalui tahapan perancangan, maka dalam tahapan proses implementasi ini harus dilakukan pengujian perangkat lunak agar dapat diketahui kelebihan dan kelemahan dari sistem yang telah dibuat agar dapat di evaluasi dan menjadi lebih baik.

Merupakan halaman utama saat user atau admin untuk mengakses aplikasi atau halaman awal saat membuka halaman utama tersebut. Dimana di halaman utama ini dapat menampilkan daftar penyakit, konsultasi, 
sejarah, info kelapa sawit dan menu untuk login ke dalam sistem pakar. Seperti gambar dibawah ini.

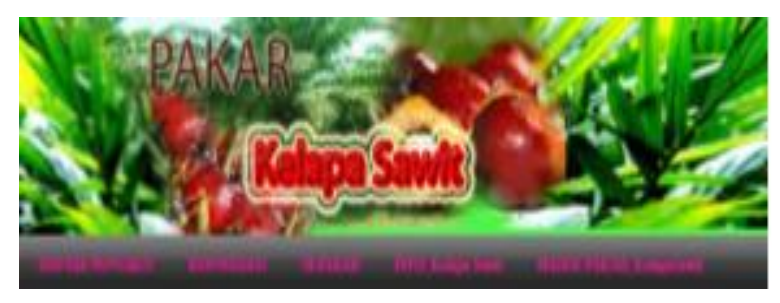

Gambar 4. Halaman Utama

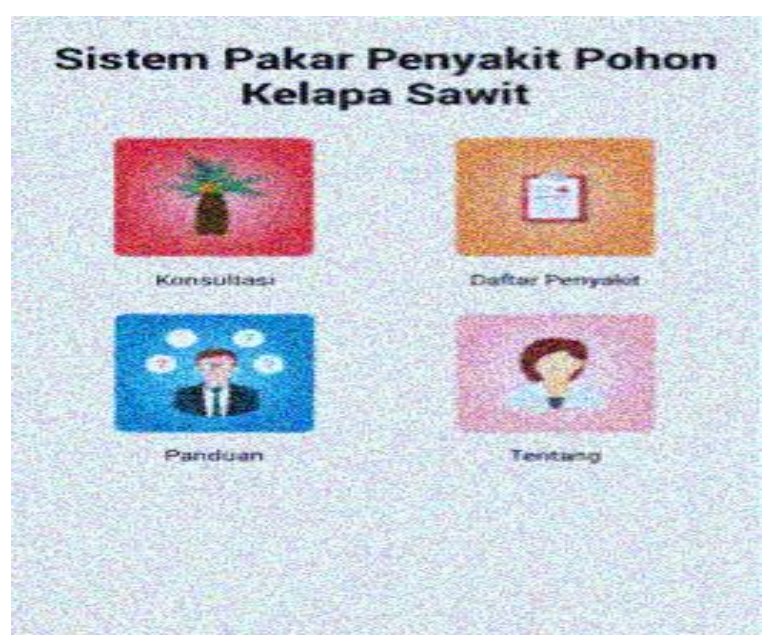

Gambar 5. Tampilan menu utama

\section{KESIMPULAN}

Berdasarkan hasil analisis dan pembahasan yang telah dilakukan maka dapat diambil kesimpulan terhadap aplikasi yang telah dibuat sebagai berikut.

a. Dapat Mempermudah user mengetahui penyakit tanaman kelapa sawit. Proses identifikasi jenis penyakit pada aplikasi ini dapat berupa sistematik konsultasi layaknya tanya jawab dengan pakar.

b. Aplikasi ini menggunakan metode forward chaining untuk mengetahui penyakit tanaman kelapa sawit dengan metode ini nilai CF berada pada kisaran 0 sampai dengan 1, jika keluaran CF mendekati satu, maka kepastiannya mendekati benar.

c. Aplikasi sistem pakar yang telah dikembangkan dapat mempermudah petani mengetahui penyakit tanaman kelapa sawit karena telah berbasis android dan mobilitasnya lebih maksimal.

\section{DAFTAR PUSTAKA}

[1] Lobo D, Kaskaloglu K, Kim C, Herbert S. Web usability guidelines for smartphones: a synergic approach. International Journal of Information and Electronic Engineering. Vol.1 no.1 pp 33-37. 2013.

[2] Cadena, T., F. Prada, A. Perea, and H.M. Romero. "Lipase activity, mesocarp oil content, and iodine value in oil palm fruits of Elaeis guineensis, Elaeis oleifera, and the interspecific hybrid $\mathrm{O} \times \mathrm{G}(\mathrm{E}$. oleifera $\times \mathrm{E}$. guineensis)", PubMed, vol. 93, no 3, pp. 674-680, 2013.

[3] Susanto, A. "Pengurangan laju infeksi penyakit busuk pangkal batang di perkebunan kelapa sawit melalui pemanfaatan lubang besar dan agensia hayati", Direktorat Jenderal Perkebunan Kementerian Pertanian. Jakarta. 2013.

[4] Connell C, Klein JH, Loebbecke C, Powe1 $\mathrm{P}$, "Toward a Knowledge Management Consultation System", Knowledge and Process Management journal, Volume 8 Number 1 pp 48-54. 2013.

[5] Maryani, Anis, "Pengaruh Volume Pemberian Air Terhadap Pertumbuhan Bibit Kelapa Sawit Di Pembibitan Utama, Bioplantae, Vol 1 No. 2, 2012.

[6] Utami, A.W., Putra, R.S., "Sistem Pakar Identifikasi Penyakit Tanaman Bawang Merah Menggunakan Metode Teorema Bayes", Jurnal Manajen Informatika, Vol. 4, No 1, 2015.

[7] Defitri Y., "Identifikasi pathogen penyebab penyakit tanaman kelapa sawit (Elaeis guinnensis) Di Desa Bertam Kecamatan Jambi luar kota", Jurnal ilmiah Universitas Batanghari Jambi, Vol. 12, No.4, 2014. 
[8] R. Fauzan and A. V. Prananda, "Expert System for Diagnosing Palm Tree Diseases and Pests using Forward Chaining and Certainty Factor," Kinetik: Game Technology, Information System, Computer Network, Computing, Electronics, and Control, Vol. 3, No. 1, pp. 27-34, 2017.

[9] Azhar, S., Sari, H. L., \& Zulita, L. N. "Sistem Pakar Penyakit Ginjal Pada Manusia Menggunakan Metode Forward Chaining", Jurnal Media Informatika, Vol.10 no.1. 2014.

[10] Wahyuni, E.G., Prijodiprodjo, W., "Prototype Sistem Pakar Untuk Mendeteksi Tingkat Resiko Penyakit Jantung Koroner Dengan Metode Dempster-Shafer", IJCS, Vol.7, No. 2, 2013. 